\title{
ECONOMIC IMPACT ANALYSIS OF APT PRANOTO AIRPORT PROJECT DURING CONSTRUCTION PHASE
}

\author{
Adisthy Shabrina Nurqamarani \\ adisthy.shabrina@gmail.com \\ Faizal Reza \\ Faculty of Economics, Universitas 17 Agustus 1945 Samarinda \\ Jl. Ir. H. Juanda No. 80, Samarinda 75124, Indonesia
}

received: 1/11/18; revised: 11/2/19; published: 31/12/19

\begin{abstract}
The aim of this research was to provide the evidence of economic benefits resulted from development of APT Pranoto airport towards East Kalimantan which will strengthen the support of the development of the new airport from various stakeholders. This research applied input-output, analysis to estimate the economic impact i.e impact of expenditure on construction phase. Direct impact includes the increase in gross value added as well as income from tax payment and create new employment. Indirect impact includes increase in capital spending of the workers and more money circulated within the area of East Kalimantan. This study conclude that there are direct and indirect impacts from APT Pranoto airport during construction phase within the period of 5 years. The findings can be used to emphasize APT Pranoto Airport Project in gaining funding and acceptance from local economy.
\end{abstract}

Keywords: input-output analysis; economic impact; impact of expenditure; gross value added

\section{INTRODUCTION}

In order to accelerate and strengthen economic development, the Indonesian government, which plays the role of planner and implementer of economic development today, made initiative to increase the development of infrastructure in areas outside of Java to become centers of new economic growth. Accordingly, the creation of equitable development in other regions in Indonesia, especially outside Java, can be achieved. Thus, infrastructure development projects in the era of President Jokowi include construction of several toll roads, flyovers, bridges, airports, and other infrastructure are spread across several provinces in Indonesia. The effect of development of infrastructures are supported by previous research who pointed out evidences of the role of infrastructure towards economic growth (Banerjee \& Esther Duflo, 2012; Darmawan, 2012; Luke \& Walters, 2010).

The relationship between appropriate infrastructure provision and economic growth is commonly recognized in academic literature (Azam, 2017; Darmawan, 2012; Haider, Amjad, Ullah, \& Naveed, 2012; Luke \& Walters, 2010). Improved infrastructure will contribute to the regional productivity growth in particular and to the overall aggregate output of the country in general and consequently will largely improve welfare of the society.
In order to stimulate regional economic development, the presence of airport plays an important role in supporting the regional economy both as a support for the needs of the community and for industrial needs. The presence of the airport is also considered important to streamline smooth activities of Indonesian citizens who resides in island nations. The role of airport towards economic development is found positive as aviation contributes to direct and indirect impacts to the economic and increase the cycles of economic activities (Darmawan, 2012; Grančay, 2009; Nasution, Azmi, Siregar, \& Erlina, 2018; Nurqamarani, 2018).

In addition, the increase need of air transport is also predicted will be larger in the future (Darmawan, 2012; IATA, 2018). Ishutkina \& Hansman (2008) stated that the growth of air transport industry has resulted into more job creations and the increase circulation of capital and goods which in return create mutual benefit as the economy will make demand for air transport. Consequently, the increase demand for air transport require government to develop an equipped airport which will accommodate those demand.

Samarinda is one of the cities in Indonesia that functions as the capital of East Kalimantan Province, while at once serves as the most populous city in East Kalimantan. However, the facts indicated that the existing airport was not capable of serving domestic 
routes between islands and major cities in Indonesia. The flow of goods and services from and to the capital of the province of East Kalimantan has been mostly accessed through the nearby city; Balikpapan, which has built an international airport (Sultan Aji Muhammad Sulaiman Sepinggan Airport) and even has renewed the airport which can accommodate 15 million passengers per year (Kaltimprov.go.id, 2015) .

Historically Samarinda Baru Airport, known as APT Pranoto airport, was designed as a substitute for the previous Samarinda airport, namely Temindung Airport which was originally built as a pioneer airport in 1973. In the early 2000s, Temindung Airport had become one of the busiest airports in East Kalimantan which exceed annual passenger and cargo design capacity. Due to a surge in air traffic that continues to increase every year and limited space for expansion of airport facilities, there is at least one delay for every 25 flights at Temindung Airport (Asprimagama, 2013). Mostly due to lack of space for aircraft, gates, and runways.

Table 1 is an overview of Temindung airport traffic during 2013-2016. Based on Table 1, Temindung Airport has experienced a continuous decline on airplane and passenger traffic at Temindung Airport since 2013. That is why the government has scheduled the construction of a new airport in the city of Samarinda which is considered able to overcome this problem.

Temindung Airport was owned by the Regional Government of East Kalimantan only served flights to several regions in East Kalimantan and North Kalimantan. Meanwhile, to add flight routes to major cities in Indonesia it was not possible due to the limited location of Temindung Airport which was near densely populated areas. Moreover, there is a restriction regarding the height of the building in Samarinda where Temindung Airport located which impede the operation of the Temindung Airport to build more representatives building to support bigger aircraft traffic flow.

Considering the impacts of infrastructure particularly airport to economic development as well as the current condition of existing airport, it urged the need to build a new airport that is more representative in the city of Samarinda. On the other hand, there is a newly refurbished airport which is located approximately 145 $\mathrm{km}$. This raises the question in the minds of the public whether the new airport would contribute sufficiently to East Kalimantan

Thus, to gain more moral and financial supports from citizens and investors, as well to estimate the impact the airport brings to the region (East Kalimantan), therefore this paper aims to estimate the impact of the construction of the APT Pranoto Airport on the economy of East Kalimantan. This study provides an estimate of additional value-added statewide benefits that East Kalimantan experiences from the development of APT Pranoto Airport during construction phase of 2013-2018.
Reksohadiprojo (2001) states that the development of a city is also influenced by its development and economic policies. He also mentioned that development of the city was basically a physical manifestation of economic development. Furthermore, Calderón et al (2004) researched that infrastructure development can be highly effective to combat poverty. These researches showed relationships between infrastructure development and economic development.

The impact of infrastructure can be seen from various studies conducted by Permana (2010), using the Input-Output Analysis method. The results of this study found that infrastructure has a backward linkage that is higher than the forward linkage which means that it increases the output in other sectors to be used as input compared to its ability to increase the output of other sectors that use input from infrastructure. Resource development in the electricity, gas and clean air sectors influences total output, while the transportation and communication sector contribute in total.

Stupak (2017) found that infrastructure is critical in the health and wealth of a country which enabling private businesses and individuals to produce goods and services more efficiently.

Several previous empirical studies have specifically been conducted to examine the relationship between economic variables and the availability of international air transport services. They have found that airport brings positive contribution towards economic development. (Air Transport Action Group (ATAG), 2004; Gittens, de Juniac, Fanning, Hocquard, \& Liu, 2018; Stupak, 2017; Transportation, 2015)

According to Gittens et. al (2018), The aviation industry is a source of considerable economic activity, creating jobs that directly serve passengers at airlines, airports and air navigation services providers. Moreover, aviation directly enables jobs in the manufacturing sector (those companies that produce aircraft, engines and other vital technologies).

(Air Transport Action Group (ATAG), 2004) imply that air transportation can contribute to the economic development through direct, indirect, and induced impacts.

Neswari (2012) concluded that the building sector (airport) has a greater backward link compared to future linkages, meaning that the construction of airports can increase the growth of the upstream sector. It was further concluded that development of airport increased output, and household expenditure in Nusa Tenggara Barat province.

However, according to (Darmawan, 2012), air transport is not the driver for economic growth, since its direct impact has been consider very little. However, the indirect and induced impact contributes more to the economic development. Hence air transport is acting more as a platform for other industry sectors to grow rather than the driver for the economic development. 
Economic impact analysis is an economic method to evaluate the economic impact of an event towards the study region. According to N'dolo (2016), The purpose of conducting an economic impact study is to ascertain the total cumulative changes in employment, earnings and output in a given economy due to some initial change in final demand.

Direct economic impacts are changes in local business activities that occur as a direct consequence of public or private business decisions. For projects related to transportation and infrastructure (airports), the most visible direct impact is certainly in terms of employment opening both within the airport itself, as well as related industries such as tourism, coal, plantations, creative economy, construction and maintenance of facilities.

In addition to direct impacts, there is a secondary impact which is divided into indirect and induced impacts. Secondary impacts are changes in economic activity from the next round of cash outflows. Using metaphors, secondary impacts can be described as 'ripple effects' in ponds where the 'ripple effect' is caused by spending new money in local areas in areas such as wages or local products (Janeczko et al., 2002).

With respect to overall economic output, increased infrastructure spending by the government is generally expected to result in higher economic output in the short term by stimulating demand and in the long term by increasing overall productivity (Stupak, 2017). In addition, it is likely to reduce the unemployment rate to some degree, during the recession period.

In the case of new airport projects, indirect impacts occur at the construction stage because the project requires additional raw materials or additional technology that requires suppliers to re-supply from producers. In addition, it also includes bankers who finance construction or accountants who store contractor books, and catering that supplies food to workers.

While the impact induced in a project can refer to as a result of additional income distributed throughout the wider economy. When workers from construction or operational activities come to the study area, local retailers will make more money because more customers buy household products and other necessity products. As a result, because more money is generated, workers' wages can increase. When workers get more money, there is a higher chance they will spend more that will drive economic growth.

The Provincial Government of East Kalimantan is currently proclaiming the construction of the Pranoto APT Airport which is projected to be the Supporting Airport of Sultan Aji Muhammad Sulaiman Sepinggan Airport, this study aims to determine the economic impact of the construction phase of APT Pranoto airport on the economy of East Kalimantan which includes the impact of expenditure direct and indirect impact.

In addition to direct and secondary impacts, multipliers are an important aspect in the analysis of economic impacts. An economic multiplier analysis will help to gain an overall understanding of the situation through estimating the impact caused by airport development on other sectors in an area (Neswari, 2012).

Another important term is called leakage in the analysis of economic impacts. Leaks occur when money is spent outside the area that is leaking in every round of expenditure. Leakage levels tend to be lower if the study area is larger. Some research shows that leaks can reduce indirect impacts. This describes transactions along the chain with suppliers outside the study area. For example, when a supplier trades outside the study area, the income that is usually generated by worker expenses will stop flowing in the study area. The impact of induced business refers to a further shift in expenditure on food, clothing, shelter and other consumer goods, as a consequence of changes in business workers and payroll which are directly and indirectly affected. This causes further business growth/decline in the entire local economy.

\section{METHOD}

This is a descriptive research which was conducted to estimate the impact of the construction phase of APT Pranoto Samarinda Airport towards East Kalimantan province. The type of method that author employed in this descriptive research is case study analysis as it specifically analyzes the impact of the construction of APT Pranoto Airport towards East Kalimantan Province. The data collection uses secondary data obtained from several sources such as airport expenditure data from the Transportation Agency of East Kalimantan Province, APT Pranoto Airport Management Unit, Angkasa Pura, companies that involved in the construction of APT Pranoto Airport, as well as other relevant publications.

The analysis method used in this paper is the multiplier analysis method which studies the effect of the construction phase of APT Pranoto Samarinda airport on the economy of East Kalimantan as a whole. The analysis includes three sub-steps; (1) measure gross value added (GVA) and estimates jobs generated from the project, (2) build inputoutput models, and (3) implement multiplier analysis which classified into construction and operational phase. In this paper, the author primarily focuses on construction phase.

The conceptual framework is presented in Figure 1. This analysis focus on estimating the direct, indirect and impact impacts of induction from APT Pranoto Airport in Samarinda through the use of multipliers (multiplier numbers). But before estimating the impact, sensitivity analysis is done to overcome the lack of data by calculating the effects of different multipliers to estimate the impact and test the sensitivity of the results. 


\section{RESULTS}

APT Pranoto Airport is in the city of Samarinda, which is the capital of the province of East Kalimantan. Therefore, the study area will cover the area of East Kalimantan. East Kalimantan Province is the second largest province after Papua. Administratively, the Province has a northern boundary bordering North Kalimantan, bordering a portion of the East (12 Miles) of the Makassar Strait and Sulawesi Sea, bordering South Kalimantan Province in the south, Central Kalimantan Province and West Kalimantan Province and the West. Sarawak Section of East Malaysia.

Based on population projection data, in 2018 the population in East Kalimantan was 3,648,835 people. Thus, by looking at the population distribution between APT Pranoto Airport and Aji Muhammad Sulaiman Sepinggan Airport, the target market prospectus for Sepinggan Airport is 1,232,686 and for APT Pranoto Airport is 2,416,149 (assuming the same route).

Figure 2 shows that from 2013 to 2017, the GVA and GDP remained relatively stable with slightly increase from 2013-2017. While for employment rate, it showed a slight fluctuate chart from 2013-2017. This means that although the construction of APT Pranoto has run from 2013-2017, it has little impact towards GVA, GDP, and employment rate of East Kalimantan. The underlying assumption is based on looking at analysis of Input Output Table issued by BPS on 2010, infrastructure sector has little contribution towards the region of East Kalimantan (Badan Pusat Statistik (BPS) and Bappeda Prov. Kalimantan Timur, 2011).

Figure 3 shows data from Departement of Tourism and Culture of East Kalimantan, and observation also showed that more restaurants are built during the construction phase from 2013-2017 which shows indirect impact of the building of the airport. The workers from APT Pranoto airport spent their money within the restaurant nearby the site which made the circulation of money and goods within the economy.

The selection of study areas covering the entire area of East Kalimantan. Due to some limitations in data collection, this research will be based on the underlying assumptions, as stated in Table 2.

Direct expenditure refers to impacts directly related to airport development and depends on capital expenditure. In this study, we need to consider the scope of the contractor to identify where the company's expenditure has an impact. Thus, the total figure for corporate spending in the area will be multiplied by the multiplier coefficient to produce indirect and induced impacts. As a final step, all direct and indirect (indirect and induced) influences will be added to give a picture of the total impact.

Table 3 shows that the total capital expenditure (Capital Expenditure) is reduced by leakage $30 \%$ by
Rp. $1,332,800,000,000.00$ with a leakage estimate of $30 \%$ obtained from the results of problem structuring with a resource person from the Transportation Agency of East Kalimantan Province who estimated the impact of leakage was only $30 \%$ because most of the project expenditure was sourced from East Kalimantan. Then the number is multiplied by the multiplier coefficient to calculate the secondary impact (indirect and induced impact). From the calculation, it was found that the impact of spending on airport projects in the construction phase of the province of East Kalimantan was the addition of money or turnover of the multiplier effect of Rp. 6,650,672,000.00 with a total impact of Rp 1,339,450,672,000.

Input-output analysis illustrates how the state economy responds to the direct capital expenditures made by the airport. The direct impact of the employment for the five year period is Rp. 1.332.800.000.000, 00, which accounts for expenditure directly related to airport.

Indirect impacts measure the amount of local economic activity generated by direct expenditures from local industries. For example, professional services such as financial advising and legal services may be contracted to local businesses to support operations. This second layer of spending illustrates how local industries are impacted by the purchasing behavior from other local industries. This represents the impact of spending as it cycles through the supply chain until all money is accounted for by either imports or contribution to GDP. In terms of airport capital expenditure for the five-year period these amount to Rp. 6.650.672.000,00 in contributions to GDP and Rp. 1.339.450.672.000,00 in total output.

Finally, the re-circulation of money from payroll results in additional contributions to employment, the GDP and total output. This recognizes that labor income does not leak from the state economy but is recirculated as household spending. However, due to data limitation, payroll data is included in total capital spending thus payroll impact cannot be specified.

To improve the accuracy of the results of this study, researchers conducted sensitivity analysis by comparing the results of several alternative multiplier numbers and calculating their impact on the economy of the province of East Kalimantan, as stated in Table 4. The multiplier number of 1.7 which is sourced from the Regional Planning and Development Agency (BAPPEDA) of Balikpapan City is chosen as an alternative multiplier.

Researchers also calculated several scenarios from different levels of leakage, as presented in Table 5. The result of sensitivity analysis shows that the impact of expenditure is highly sensitive to the leakage rate. Therefore, it is necessary to consider the leakage level of the impact. Unfortunately, government has little concern on the data from contractors who build the project. There is lack of information of where the 
materials come from, how many workers are hired and where the workers are domiciled which impact to the accuracy of the research. It is important to keep most sources from the region of East Kalimantan to ensure most economic impact flows within the region. There is a possibility why the development of APT Pranoto has slight impact towards the GDP, which is the high leakage level whereby most of the materials are coming from outside the region.

There are many jobs in East Kalimantan that are in some ways supported by the construction of APT Pranoto airport. These jobs are primarily in construction industry, and also associated with onairport businesses, tenants, and other activities that are located on commercial or general aviation airports.

Another impact from the development of APT Pranoto Airport would be from non-pecuniary aspect. The Development of APT Pranoto airport would likely to attract highly skilled workers to the area since the project required such expertise. Thus, it will benefit East Kalimantan region as these skilled workers would transfer the knowledge to the local workers which will lead to more learning opportunities and increase the competitive advantage of the region.

\section{DISCUSSIONS}

Results from this research showed that infrastructure development in the form of construction of APT Pranoto Airport brings monetary impact towards East Kalimantan Economy. During the period of 5 years, economic activity or output generated by the airports and activities they support totals of Rp. 1.339.450.672.000, 00 , with the estimated leakage of $30 \%$. There are another value-added include non-aviation jobs that are in some way reliant on the airports.

These results are supported by Stupak (2018) stated that Investments in core infrastructure, defined as roads, railways, and airports, are expected to produce larger gains in economic output than investments in some broader types of infrastructure.

Previous researches also showed that infrastructure development lower down unemployment rate (Neswari, 2012; Permana, 2009; Stupak, 2018)

Nevertheless, despite of the benefit of the building of the new airport, there are some critiques associated as a result of observation which are the lack of synchronization of the work of the Transportation Agency and the Public Works Agency in the construction of the Airport project. The airport building is established in the middle of 2018, yet the airport access is still not standardized enough as the road is still perforated, in some areas the width of the road is too narrow for two cars to pass, access to the airport is not yet feasible and is often flooded during heavy rains. This should be the government's attention if this project to run optimally.

\section{CONCLUSIONS}

The development of airport infrastructure is theoretically thought to have a large economic impact on the region. Its importance is crucial for both carriage of passengers and goods. However, little attention has been research about the role of the airport towards the economic development of the region. Therefore, this research is carried out by using multiplier analysis to find out the expenditure impact and tracking out ripple effects as the expenditures create money circulates within the region.

Economic benefits such as increasing spending and creating new jobs lead to an increase in local GDP. The results of this study indicate the construction phase of the APT Pranoto airport has slight economic impact on the economy of the province of East Kalimantan, namely in the form of increased expenditure and Gross Value Added, though not significantly influence as seen at GVA and GDP data of East Kalimantan earlier.

However, the multiplier analysis is fragile as the multiplier coefficients can vary considerable between locations and alter during different period which becomes major limitation of this paper. Thus, sensitivity analysis is made to increase the accuracy of the findings. The result from sensitivity analysis shows the estimated economic impact is affected by the multiplier coefficient. Thus, having an accurate and latest multiplier coefficient in the study region is crucial for the robustness of the research.

\section{ACKNOWLEDGEMENT}

This resesarch is supported and funded by Direktorat Jendral Penguatan Riset dan Pengembangan Kementerian Riset, Teknologi, dan Pendidikan Tinggi, No. 509/KONTRAK-PENELITIAN/K11/KM/2018.

\section{REFERENCES}

Air Transport Action Group. 2004. The economic \& social benefits of air transport Contents. Retrieved from https://www.icao.int/Meetings/ wrdss2011/Documents/JointWorkshop2005/ ATAG_SocialBenefitsAirTransport.pdf

Asprimagama, R. 2013. Implementasi Tanggung Jawab Pengangkut Mengenai Ganti Kerugian Atas Keterlambatan Angkutan Udara Pada Bandara Temindung. The University of Mulawarman, 9.

Azam, M. and Bakar, N.A.A., 2017. The Role of Infrastructure in National Economic Development: Evidence from Malaysia. International Journal of Economic Perspectives, 11(4).

Badan Pusat Statistik (BPS) dan Bappeda Prov. Kalimantan Timur. 2011. Tabel Input Output Kalimantan Timur.

Banerjee, A., \& , Esther Duflo, and N. Q. 2012. On 
the Road: Access to Transportation Infrastructure and Economic Growth in China.

BPS Kalimantan Timur. 2018. GVA, GDP, and Employment Rate in East Kalimantan.

Calderón, C.A. and Serven, L., 2014. The effects of infrastructure development on growth and income distribution. Annals of Economics and Finance, 15(2), pp.521-534.

Dharmawan, I.G.N.I., 2012. The effect of air transport to economic development in Indonesia. Erasmus University.

Departement of Tourism and Culture of Kalimantan Timur. 2017. Data of Restaurant in East Kalimantan from 2013-2017.

Direktorat Jendral Perhubungan Udara. 2017. Lalu Lintas Angkatan Udara. Retrieved from http:// hubud.dephub.go.id/?id/llu/index/filter:airport 45

Gittens, A., de Juniac, A., Fanning, E., Hocquard, S., \& Liu, F. 2018. Aviation Benefits Report. Industry High Level Group, 74. Retrieved from https://www. icao.int/sustainability/Pages/IHLG.aspx

Grančay, M. 2009. Munich Personal RePEc Archive The economic impacts of air transport liberalization The Economic Impacts of Air Transport Liberalization.

Haider, S. Z., Amjad, M. U., Ullah, S., \& Naveed, T. A. 2012. Role of Infrastructure in Economic Growth : A Case Study of Pakistan. Asian Development Studies, 1(1), 13-21.

IATA. 2018. IATA Forecast Predicts 8.2 billion Air Travelers in 2037. Retrieved from International Air Transport Association (IATA) website: https://www. iata.org/en/pressroom/pr/2018-10-24-02/

Ishutkina, M. A., \& Hansman, R. J. 2008. Analysis of interaction between air transportation and economic activity. 8th AIAA Aviation Technology, Integration and Operations (ATIO) Conference, 1-18. https:// doi.org/10.2514/6.2008-8888

Janeczko, B., Mules, T. and Ritchie, B.W., 2002. Estimating the economic impacts of festivals and events: a research guide (pp. 1-46). Queensland: $\mathrm{CRC}$ for Sustainable Tourism.
Kaltimprov.go.id. 2015. Bandara Internasional Sultan Aji Muhammad Sulaiman Sepinggan Balikpapan menempati urutan ke-16. Retrieved from Provinsi Kaltim website: https://web.archive. org/web/20150619094621/http://www.kaltimprov. go.id/berita-5602-bandara-internasional-sultanaji-muhammad-suliaman-sepinggan-balikpapanmenempati-urutan-ke16.html

Luke, R., \& Walters, J. 2010. The Economic Impact Of South Africa's International Airports. Journal Of Transport And Supply Chain Management, 120-137.

Nasution, A. A., Azmi, Z., Siregar, I., \& Erlina, I. (2018). Impact of Air Transport on the Indonesian Economy. MATEC Web of Conferences, 236. https://doi. org $/ 10.1051 /$ matecconf $/ 201823602010$

N'dolo, R. M. 2016. What is Economic Impact Analysis? Retrieved March 15, 2018, from https://www. camoinassociates.com/what-economic-impactanalysis

Neswari, K. E. N. A. 2012. Dampak pembangunan bandara internasional lombok terhadap perekonomian provinsi nusa tenggara barat.

Nurqamarani, A.S. and Reza, F., 2018. Analisis Dampak Pembangunan Samarinda Baru (Bsb) Terhadap Provinsi Kalimantan Timur. Research Journal of Accounting and Business Management, 2(2), pp.161-175.

Permana, C.D., 2010. Analisis Peranan dan Dampak Investasi Infratsruktur terhadap Perekonomian Indonesia. Bogor: Fakultas Ekonomi dan Manajemen Institut Pertanian Bogor (IPB).

Reksohadiprodjo, S., 2001. Ekonomika Publik. BPFEUGM. Yogyakarta.

Stupak, J.M., 2017. Economic Impact of Infrastructure Investment.

Transportation, W. D. of. (2015). Economic Impact Appleton International Airport (ATW) 2015 Airports and economic development. Retrieved from https://wisconsindot.gov/Documents/projects/ multimodal/air/atw-eis.pdf 
Table 1. Temindung Airport Traffic on 2011-2016

\begin{tabular}{|c|c|c|c|c|c|}
\hline Year & Description & Departure & Arrival & Transit & Local \\
\hline \multirow[t]{5}{*}{2011} & Planes & 2909 & 2906 & & - \\
\hline & Passengers & 48638 & 44184 & 3686 & \\
\hline & Bagage & 300372 & 390170 & & \\
\hline & Cargo & 60630 & 172414 & & \\
\hline & Post & - & - & & \\
\hline \multirow[t]{5}{*}{2013} & Planes & 3721 & 3718 & & - \\
\hline & Passengers & 65717 & 55320 & 1168 & \\
\hline & Bagage & 377203 & 375875 & & \\
\hline & Cargo & 75820 & 162831 & & \\
\hline & Post & - & - & & \\
\hline \multirow[t]{5}{*}{2014} & Planes & 2328 & 2327 & & - \\
\hline & Passengers & 53544 & 44991 & 1057 & \\
\hline & Bagage & 303284 & 258380 & & \\
\hline & Cargo & 97427 & 158423 & & \\
\hline & Post & - & - & & \\
\hline \multirow[t]{5}{*}{2015} & Planes & 2589 & 2609 & & - \\
\hline & Passengers & 50292 & 41556 & 1 & \\
\hline & Bagage & 279426 & 235866 & & \\
\hline & Cargo & 87700 & 115699 & & \\
\hline & Post & - & - & & \\
\hline \multirow[t]{5}{*}{2016} & Planes & 538 & 538 & & - \\
\hline & Passengers & 11156 & 9505 & - & \\
\hline & Bagage & 63289 & 51593 & & \\
\hline & Cargo & 24072 & 18619 & & \\
\hline & Post & - & - & & \\
\hline
\end{tabular}

Table 2. Assumptions Table

\begin{tabular}{ll}
\hline \multicolumn{1}{c}{ Issue } & \multicolumn{1}{c}{ Assumptions } \\
\hline Wages and & $\begin{array}{l}\text { Due to the nature of the project which is lump-sum/ } \\
\text { turnkey project, thus the expenditure for wages and } \\
\text { salary during the construction phase are included } \\
\text { into total project expenditure. }\end{array}$ \\
\hline Domicile of & $\begin{array}{l}\text { Majority of workers employed during the } \\
\text { Construction phase are assumed domiciled in }\end{array}$ \\
& $\begin{array}{l}\text { East Kalimantan with the reason of the location } \\
\text { of three major contractors have branch office in } \\
\text { East Kalimantan and probably hire local workers. }\end{array}$ \\
\hline $\begin{array}{l}\text { Spending } \\
\text { Patterns and }\end{array}$ & $\begin{array}{l}\text { Due to the difficulty on gaining data from } \\
\text { contractors and after problem structuring with }\end{array}$ \\
Suppliers & $\begin{array}{l}\text { Kalimantan Timur, thus it is estimated that } 70 \\
\text { Ko of the total spendings are circulated from and }\end{array}$ \\
& within East Kalimantan.
\end{tabular}

Table 3. Impact of Development of APT Pranoto Airport During Construction Phase

\begin{tabular}{lr}
\hline \multicolumn{1}{c}{ Keterangan } & \multicolumn{1}{c}{ Total } \\
\hline Est. Capital Expenditure & Rp. $1.904 .000 .000 .000,00$ \\
Minus Leakage 30\% & Rp. $571.200 .000 .000,00$ \\
Direct Expenditure Impacts & Rp. $1.332 .800 .000 .000,00$ \\
Multiplier Coefficient & 1,00499 \\
Est. Indirect and Induced Impact & Rp. 6.650.672.000,00 \\
\hline Total Impact (Combined Direct, & Rp. 1.339.450.672.000,00 \\
indirect, and Induced Impact) & \\
\hline
\end{tabular}

Source: (Direktorat Jendral Perhubungan Udara, 2017)

Table 4. Estimated Impact towards the Economic Development

\begin{tabular}{lrl}
\hline \multicolumn{1}{c}{ Multiplier Coefficient } & $\begin{array}{c}\text { Estimated Indirect and } \\
\text { Induced Impact }\end{array}$ & Total Expenditure Impact \\
\hline 1.7 (Bappeda Balikpapan, 2015) & Rp. 161,648,776.07 & Rp. 2,265,760,000,000.00 \\
1.00499 (Original Coefficient- BPS, 2010) & Rp. 932,960,000,000.00 & Rp. 1,339,450,672,000.00 \\
\hline
\end{tabular}

Table 5. Sensitivity Analysis

\begin{tabular}{crrr}
\hline Leakage & Direct Expenditure & Indirect Expenditure & \multicolumn{1}{c}{ Total Expenditure } \\
\hline $20 \%$ & Rp. $1.523 .200 .000 .000,00$ & Rp. $600.768 .000,00$ & Rp. $1.530 .800 .768 .000,00$ \\
$30 \%$ & Rp. $1.332 .800 .000 .000,00$ & Rp. $650.672 .000,00$ & Rp. $1.339 .450 .672 .000,00$ \\
$40 \%$ & Rp. $1.142 .400 .000 .000,00$ & Rp. $700.576 .000,00$ & Rp. $1.148 .100 .576 .000,00$ \\
$50 \%$ & Rp. $952.000 .000 .000,00$ & Rp. $750.480 .000,00$ & Rp. $956.750 .480 .000,00$ \\
$60 \%$ & Rp. $761.600 .000 .000,00$ & Rp. $800.384 .000,00$ & Rp. $765.400 .384 .000,00$ \\
$70 \%$ & Rp. $571.200 .000 .000,00$ & Rp. $850.288 .000,00$ & Rp. $574.050 .288 .000,00$ \\
$80 \%$ & Rp. $380.800 .000 .000,00$ & Rp. $900.192 .000,00$ & Rp. $382.700 .192 .000,00$ \\
\hline
\end{tabular}




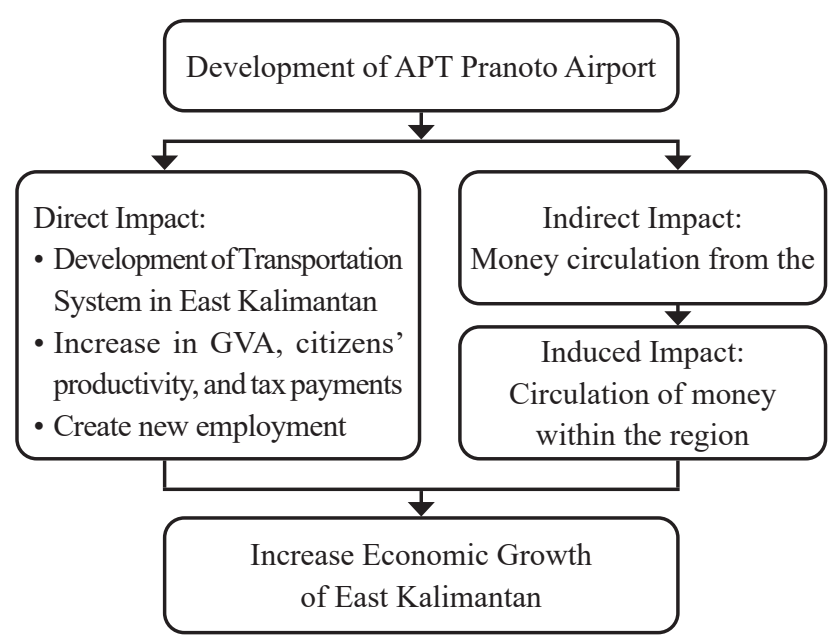

Figure 1. Research Framework

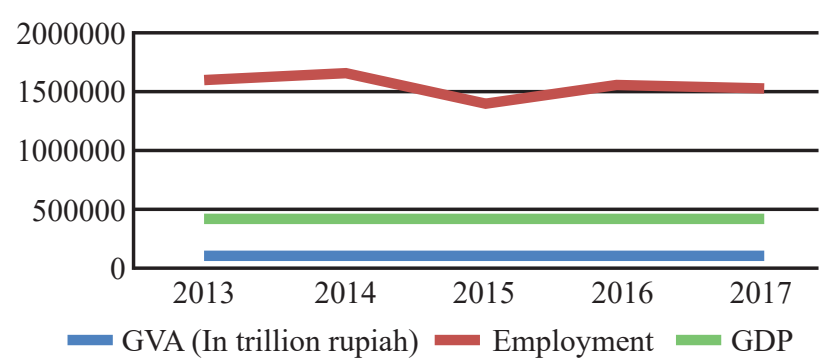

Source: (BPS Kalimantan Timur, 2018)

Figure 2. Brief Description of GVA, GDP, and Employment Rate in East Kalimantan

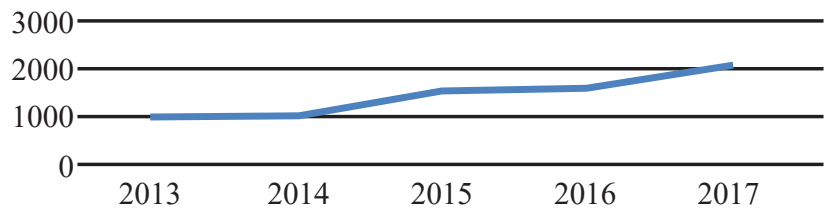

Source: (Department of Tourism and Culture of Kalimantan Timur, 2017)

Figure 3. Data of Restaurant in East Kalimantan from 2013-2017 